\title{
MicroRNA Profiles of Drug-Resistant Myeloma Cell Lines
}

\author{
Reinhold Munker ${ }^{a}$ Chang-Gong Liu ${ }^{b}$ Cristian Taccioli ${ }^{b}$ Hansjuerg Alder ${ }^{b}$ \\ Nyla Heeremac \\ a Division of Hematology/Oncology, Louisiana State University, Shreveport, La., and Departments of \\ ${ }^{\mathrm{b}}$ Molecular Virology, Immunology and Human Genetics and ' Pathology, Ohio State University, \\ Columbus, Ohio, USA
}

Drug resistance is one of the reasons for treatment failure in hematologic and other malignancies. MicroRNAs are small noncoding RNAs involved in the initiation and progression of human cancer. MicroRNA expression profiles were found useful for the diagnosis, staging and assessment of the prognosis of human cancer [1]. The microRNA expression profile of human myeloma was recently characterized and compared with the signature of normal plasma cells and plasma cells isolated from patients with monoclonal gammopathy of unknown significance. Some of these microRNAs modulate the expression of proteins critical to the pathogenesis of myeloma [2]. Drug resistance can be de novo or acquired and is one of the reasons why cancer treatment fails. We previously characterized a leukemia cell line resistant to cyclophosphamide by gene expression profiling [3]. In multiple myeloma, drug-resistant cell lines were developed as a model for acquired drug resistance [4]. We here asked the question if a microRNA resistance profile exists for 2 myeloma cell lines (RPMI8226 and U266) made resistant to 2 common cytostatic drugs (melphalan and doxorubicin) which would ultimately be useful for prognosticating clinical resistance in patient samples.

The cell lines RPMI8226 and U266 and their resistant variants RPMI8226/Dox6 and RPMI8226/LR5, respectively U266Dox and U266/LR7 were obtained from Drs.
Bharat Aggarwal (M.D. Anderson Cancer Center, Houston, Tex., USA) and Atanasio Pandiella (Salamanca, Spain). All 4 resistant cell lines originated from Dr. William Dalton (H. Lee Moffitt Cancer Center and Research Institute, Tampa, Fla., USA). The cell lines were cultured in RPMI 1640 supplemented with $10 \%$ fetal calf serum and penicillin-streptomycin according to standard tissue culture conditions. RPMI8226/Dox6 was pulsed once weekly with $6 \times 10^{-8} \mathrm{M}$ doxorubicin, whereas RPMI8226/ LR5 was pulsed once weekly with $5 \times 10^{-6} \mathrm{M}$ melphalan.

For cytogenetics, exponentially growing cells from each of the cell lines were fixed using standard laboratory procedures. Cell suspensions were prepared and dropped onto precleaned, warm, wet slides. The slides were aged at $90^{\circ} \mathrm{C}$ for $1 \mathrm{~h}$, banded with trypsin and stained with Wright stain. Banded metaphases were analyzed using a Zeiss Axioskop 40 microscope. For each cell line, metaphases were karyogramed with an Applied Imaging Karyotyping System. The metaphases were described using ISCN nomenclature [5].

The results of these analyses showed that although distinct, both the Dox6 and LR4 resistant cell lines were closely related to their parental cell line, RPMI8226, and similarly that although distinct both, the U266Dox and U266/LR7 cell lines were closely linked with their parental cell line, U266.

\section{KARGER}

() 2010 S. Karger AG, Basel

Fax +41613061234 E-Mail karger@karger.ch www.karger.com www.karger.com/aha
Reinhold Munker, MD

Louisiana State University Health Sciences Center, Division of Hematology/Oncology 1501 Kings Highway

Shreveport, LA 71130 (USA)

Tel. +1 318675 8770, Fax +1 318675 4969, E-Mail rmunke@lsuhsc.edu 
Table 1. Comparison of microRNA patterns among different myeloma cell lines by microarray chip analysis

\begin{tabular}{|c|c|c|c|}
\hline Type of comparison & Results & Type of comparison & Results \\
\hline $\begin{array}{l}\text { U266 parent } \\
\text { versus U266 Dox }\end{array}$ & $\begin{array}{l}\text { Overexpressed: } 9 \text { microRNAs } \\
\text { (miR769[2.60], miR497[1.94], } \\
\text { miR619[1.96], miR99[3.38], } \\
\text { miR565[4.43], miR324[2.55], } \\
\text { miR602[2.48], miR152[2.92], } \\
\text { miR338[5.71]) } \\
\text { Underexpressed: } 16 \text { microRNAs } \\
\text { (miR181[0.123], miR342[0.163], } \\
\text { miR213[0.166], miR191[0.335], } \\
\text { miR21[0.365], miR215[0.253], } \\
\text { miR95[0.35], miR138[0.423], } \\
\text { miR155[0.516], miR34b[0.326], } \\
\text { miR150[0.434], miR129[0.507], } \\
\text { miR34a[0.424], miR222[0.402], } \\
\text { miR197[0.53], miR148[0.533]) }\end{array}$ & \multirow[t]{2}{*}{$\begin{array}{l}\text { RPMI8226 parent } \\
\text { versus RPMI8226 } \\
\text { LR5 }\end{array}$} & $\begin{array}{l}\text { Overexpressed: } 12 \text { microRNAs } \\
\text { (miR103[1.95], miR26[2.81], } \\
\text { miR373[3.31], miR181[3.07], } \\
\text { miR213[2.88], miR768[2.47], } \\
\text { miR21[3.65], miR146[2.28], } \\
\text { miR629[4.53], let-7[4.41], miR205[4.81], } \\
\text { miR551[9.31]) } \\
\text { Underexpressed: } 21 \text { microRNAs } \\
\text { (miR591[0.34], miR548[0.24], } \\
\text { miR644[0.29], miR7-2[0.409], } \\
\text { miR338[0.385], miR324[0.384], } \\
\text { miR204[0.421], miR181[0.274], } \\
\text { miR30[0.294], miR329[0.425], } \\
\text { miR629[0.297], miR328[0.412], } \\
\text { miR639[0.405], miR598[0.463], }\end{array}$ \\
\hline $\begin{array}{l}\text { U266 parent } \\
\text { versus U266 LR7 }\end{array}$ & $\begin{array}{l}\text { Overexpressed: } 8 \text { microRNAs } \\
\text { (miR219[2.42], miR152[2.09], } \\
\text { miR494[3.82], miR21[2.09], } \\
\text { miR594[2.56], miR99[4.23], }\end{array}$ & & $\begin{array}{l}\operatorname{miR} 657[0.53], \operatorname{miR} 487[0.494] \\
\operatorname{miR} 603[0.505], \operatorname{miR} 589[0.463] \\
\operatorname{miR} 196[0.51], \operatorname{miR} 548[0.405] \\
\operatorname{miR} 213[0.535])\end{array}$ \\
\hline
\end{tabular}
$\operatorname{miR} 218$ [5.11], miR338[5.59]) Underexpressed: 10 microRNAs (miR181[0.058], miR213[0.134], $\operatorname{miR} 148 \mathrm{a}[0.422], \operatorname{miR} 197[0.384]$, $\operatorname{miR} 128[0.373], \operatorname{miR} 194[0.385]$, miR148b[0.509], miR150[0.521], miR15[0.281], miR182[0.547])

RPMI8226 parent versus RPMI8226 Dox

\section{Overexpressed: 21 microRNAs} (miR30[2.13], miR24[2.23], miR123[2.10], miR26[2.45], miR181[2.38], miR320[2.66], miR181[2.95], miR15[2.00], let7[1.98], miR103[2.80], miR768[2.68], miR182[2.63], miR7-3[2.33], miR107[2.34], miR103[2.50], miR221[4.30], miR346[4.07], miR21[8.96], miR146[9.01], miR551[19.3], miR155[120.4]) Underexpressed: 26 microRNAs (miR181[0.01], miR548[0.20], miR598[0.23], miR548[0.163], miR576[0.233], miR363[0.182], miR644[0.21], miR629[0.334], miR591[0.387], miR196[0.406], miR338[0.297], miR7-2[0.303], miR603[0.354], miR328[0.429], miR145[0.386], miR219[0.39], miR212[0.497], miR135[0.323], miR126[0.548], miR548[0.409], miR320[0.512], miR497[0.506], miR184[0.441], miR596[0.529], miR324[0.568], miR639[0.553])
Over-/underexpressed: in resistant clone, listed in order of statistical significance, in square brackets the fold over-respectively underexpression is given.

Screening cytogenetics were performed on all 6 cell lines according to standard methods and showed, based on 2 metaphases of each cell line counted, a close relationship of the resistant with the parental lines (data not shown).

Total RNA isolation was performed using the Trizol method (Invitrogen) according to the manufacturer's instructions. RNA labeling and hybridization on microRNA array was performed as described previously [6]. Briefly, $5 \mu \mathrm{g}$ of total RNA from each sample was biotin labeled by reverse transcription using $5^{\prime}$ biotin end-labeled random octamer oligo primer. Hybridization of biotin-labeled cDNA to gene-specific microRNA probes was carried out on an microRNA microarray chip (OSU version 4.0), which contains 1,600 microRNA oligoprobes derived from 474 human and 373 mouse microRNA genes and printed in duplicates. Hybridization signal amplification was performed by biotin affinity binding of probe/target complex with a Streptavidin Alexa-647 conjugate and detected by using Axon Scanner 4000B (Axon Instrument Inc., Calif., USA). The images were quantified by Gene Pix 6.0 software (Axon Instrument Inc.). For the microarray experiments, duplicate samples were used. 
Average values of the replicate spots of each microRNA were background subtracted, normalized (global median method) and further analyzed with Bioconductor, which is an open source and open development software project for the analysis and comprehension of genomic data (www.bioconductor.org).

Finally, the microRNAs measured were selected as present in at least as many samples as the smallest class in the data set (50\%). Absent calls were thresholded to 4.5 ( $\log 2$ scale) before statistical analysis, representing the average minimum intensity level detectable in the system.

MicroRNA signatures were determined by class prediction using BRB tools (http://linus.nci.nih.gov/BRBArrayTools.html) that calculates a crossvalidated misclassification rate and performs a permutation test to determine if the crossvalidated misclassification rate is lower than would be expected by chance.

Six methods of prediction were performed: compound covariate predictor, diagonal linear discriminant analysis, nearest neighbor, nearest centroid and support vector. The criterion for inclusion of a gene in the predictor is a $\mathrm{p}$ value less than a specified threshold value (0.05). The output contains the result of the permutation test on the crossvalidated misclassification rate and a listing of genes that comprise the predictor, with parametric $\mathrm{p}$ values for each gene and the CV-support percent.

The single-tube Taq Man MicroRNA Assays were used to detect and quantify mature microRNAs on Applied Biosystems Real-Time PCR instruments. All reagents, primers and probes were obtained from Applied Biosystems (Applied Biosystems, Foster City, Calif., USA). All RNA samples were normalized with RNU6B. Triplicate RNA samples were used. Reverse transcriptase (RT) reactions and real-time PCR were performed according to the manufacturer's protocols except that we used half volumes, $7.5 \mu \mathrm{l}$ for the RT reaction and $10 \mu \mathrm{l}$ for the PCR reaction, respectively. RNA concentrations were determined with a Nanodrop (Nanodrop Technologies, Inc.). One nanogram RNA per sample was used for the assays. All RT reactions, including no-template controls and RT minus controls, were run in a Gene Amp PCR 9700 Thermocycler (Applied Biosystems). Gene expression levels were quantified with the ABI Prism 7900HT sequence detection system (Applied Biosystems). Comparative real-time PCR was performed in triplicate, including no-template controls. Relative expression was calculated using the comparative $\mathrm{C}_{\mathrm{t}}$ method.

The results of the chip analysis are shown in table 1 . When the individual resistant cell lines were compared
Table 2. Verification of chip data by RT-PCR for selected MicroRNAs

\begin{tabular}{llll}
\hline Cell line & miR21 & miR181a/b & miR565 \\
\hline U266 Dox R & $0.35 \mathrm{c}$ & $0.11 \mathrm{c}$ & $0.48 \mathrm{~d}$ \\
U266 Mel R & $1.86 \mathrm{c}$ & $0.15 \mathrm{c}$ & $0.23 \mathrm{~d}$ \\
RPMI Dox R & $9.61 \mathrm{c}$ & $3.55 \mathrm{c}$ & $0.89 \mathrm{~d}$ \\
RPMI Mel R & $1.99 \mathrm{c}$ & $5.23 \mathrm{c}$ & $1.26 \mathrm{c}$ \\
\hline
\end{tabular}

Relative gene expression tested by RT-PCR compared with parental line ( $\mathrm{c}=$ concordant changes; $\mathrm{d}=$ discordant changes).

with the respective parental cell lines, multiple microRNAs were up- or downregulated. For 3 microRNAs (miR21, miR181a/miR181b and miR565), the results were verified by real-time PCR and showed concordance in 9 comparisons and discrepancies in 3 (table 2, the discrepant results were in a low expressed microRNA). According to the chip analysis, no microRNAs were commonly dysregulated in the resistant versus the parental clones. Only 1 microRNA (miR21) was commonly upregulated in the melphalan-resistant versus parental clones (confirmed by RT-PCR). However, when the drugresistant clones of U266 and RPMI8226 were compared with their individual parents, there were 22 changes common to the RMPI8226 resistant clones (11 up- and 11 downregulated) and 6 changes common to the U266 resistant clones (1 up- and 5 downregulated). It will be interesting to test if the antagonization of miR21 reverses the resistance of myeloma cell lines to melphalan. Overall, our results argue for the involvement of multiple individual changes, as far as microRNAs are concerned, in drug-resistant cell lines or for random gains and losses of genetic material during the induction of drug resistance. In all systems, multiple pathways are activated in cell line models and clinical samples resistant to cytostatic drugs (e.g. detoxifying enzymes, multidrug efflux pumps and antiapoptotic genes; for a review, see [7]). Using gene arrays, a complex gene expression pattern involving genes of the Fanconi anemia DNA repair pathway was identified in myeloma cell lines resistant to melphalan [8]. In ovarian cancer cells made resistant to paclitaxel and cisplatin, 6 microRNAs were found to be divergently expressed (let-7e, miR30c, miR125b, miR130a and miR-335) [9]. In 2 non-small-cell lung cancer cell lines, the in vitro resistance to TRAIL was found to correlate with the overexpression of miR221 and miR222 [10]. In the human breast cancer cell line MCF-7, made 
resistant to doxorubicin, 181 microRNAs were differentially expressed (165 upregulated and 16 downregulated) [11]. Among these overexpressed microRNAs, only 3 were overexpressed in the doxorubicin-resistant clone of RPMI8226 (let7, miR21, miR155), and none were overexpressed in our doxorubicin-resistant clone of the cell line U266. Taken together, multiple genetic events, some of which may be random, take place in the generation of drug resistance. The field is open for discoveries of how the different genes, pathways and microRNAs interact in the acquired or de novo resistance to drugs and ligands.
Ultimately, the question needs to be resolved if and which microRNAs can be used to diagnose and overcome resistant phenotypes in cancer.

\section{Acknowledgements}

The authors thank Drs. Flavia Pichiorri, Rami Aqeilan and Carlo M. Croce for helpful discussions, the National Cancer Institute for grant support and Jadwiga Labanowska for her technical assistance. R.M. thanks Louisiana State University in Shreveport for being granted a leave of absence (mini-sabbatical).

\section{References}

1 Calin GA, Croce CM: MicroRNA signatures in human cancers. Nature Rev Cancer 2006; 6:857-866.

2 Pichiorri F, Suh SS, Ladetto M, Kuehl M, Palumbo T, Aqeilan RI, Croce CM: MicroRNAs regulate critical genes associated with multiple myeloma pathogenesis. Proc Natl Acad Sci USA 2008;105:12885-12890.

3 Bao F, Polk P, Nordberg ML, Veillon DM, Sun A, Deininger M, Murray D, Andersson BS, Munker R: Comparative gene expression analysis of a chronic myelogenous leukemia cell line resistant to cyclophosphamide using oligonucleotide arrays and response to tyrosine kinase inhibitors. Leuk Res 2007;31: 1511-1520.
4 Bellamy WT, Dalton WS, Gleason MC, Grogan TM, Trent JM: Development and characterization of a melphalan-resistant human multiple myeloma cell line. Cancer Res 1991; 51:995-1002.

5 Shaffer LG, Tommerup N (eds): ISCN: An International System for Human Cytogenetic Nomenclature. Basel, Karger, 2005.

6 Liu CG, Spizzo R, Calin GA, Croce CM: Expression profiling of microRNA using oligo DNA arrays. Methods 2008;44:22-30.

7 Mimeault M, Hauke R, Batra SK: Recent advances on the molecular mechanisms involved in the drug resistance of cancer cells and novel targeting therapies. Clin Pharmacol Ther 2008;83:673-691.
8 Hazlehurst LA, Enkemann SA, Beam CA, Argilagos RF, Painter J, Shain KH, Saporta S, Boulware D, Moscinski L, Alsina M, Dalton WSl: Genotypic and phenotypic comparisons of de novo and acquired melphalan resistance in an isogenic multiple myeloma cell line model. Cancer Res 2003;63:7000-7006.

$\checkmark 9$ Sorrentino A, Liu CG, Addario A, Peschle C, Scambia G, Ferlini C: Role of microRNAs in drug-resistant ovarian cancer cells. Gynecol Oncol 2008;111:478-486.

10 Garofalo M, Quintavalle C, Di Leva G, Zanca C, Romano G, Taccioli C, Liu CG, Croce CM, Condorelli G: MicroRNA signatures of TRAIL resistance in human non-small cell lung cancer. Oncogene 2008;27:3845-3855.

11 Chen GQ, Zhao ZW, Zhou HY, Liu YJ, Yang HJ: Systematic analysis of microRNA involved in resistance of the MCF-7 human breast cancer cell to doxorubicin. Med Oncol 2009; E-pub May 2009. 